\title{
Traumatic Dislocation of Testis in Penile Shaft
}

Pawan Kumar Meena ${ }^{1 *}$, Sangeeta Meena ${ }^{2}$, N. K. Soni ${ }^{3}$

${ }^{1}$ Consultant in General Surgery Department, LSM Hospital Makrana, Rajasthan, India

${ }^{2}$ Consultant in Anaesthesia Department, LSM Hospital Makrana, Rajasthan, India

${ }^{3}$ Consultant Orthopaedics Department in LSM Hospital Makrana, Rajasthan, India

DOI: $10.36347 /$ sjams.2020.v08i08.020

| Received: 13.08.2020 | Accepted: 21.08.2020 | Published: 26.08.2020

*Corresponding author: Pawan Kumar Meena

Abstract

Case Report

Traumatic dislocation of testis is rare, if dislocation of testis in the same side subcutaneous plane of penile shaft was rarest. Migration of testis outside the scrotum was most commonly in superficial inguinal canal due to direct traumatic impact.

Keywords: Trauma, Testis Dislocation.

Copyright @ 2020: This is an open-access article distributed under the terms of the Creative Commons Attribution license which permits unrestricted use, distribution, and reproduction in any medium for non-commercial use (NonCommercial, or CC-BY-NC) provided the original author and source are credited.

\section{INTRODUCTION}

Mostly direct high velocity blunt traumatic impact on scrotum causing testis dislocation, most frequently to the superficial inguinal region. Dislocation of the testis is commonly unilateral but it can be bilateral in approximately $30 \%$ of patients [1].

\section{Case Report}

A 40 year old male came in OPD with history of fall from bike with minor head injury and pain over left shoulder. On examination $5 \mathrm{~cm}$ lacerated wound was found over scalp, stitching done and advised $\mathrm{x}$ ray of left shoulder joint, there was a fracture in greater tuberosity of humerus, for which orthopedician managed him conservatively. During the time of review he complained swelling and pain over shaft of penis, on examination found painful mobile lump over left lateral aspect of penile shaft approx. $3 \times 3 \mathrm{~cm}$ in size with empty left scrotal sac and normal right side scrotum (Figure1). To confirm about testis dislocation we went for ultrasonography which suggested that the testis situated in penile shaft in subcutaneous plane with intact blood supply. The patient was surgically managed through inguinal approach, the testis was reduced in scrotal pouch and orchidopexy done under spinal anaesthesia (Figure-2).

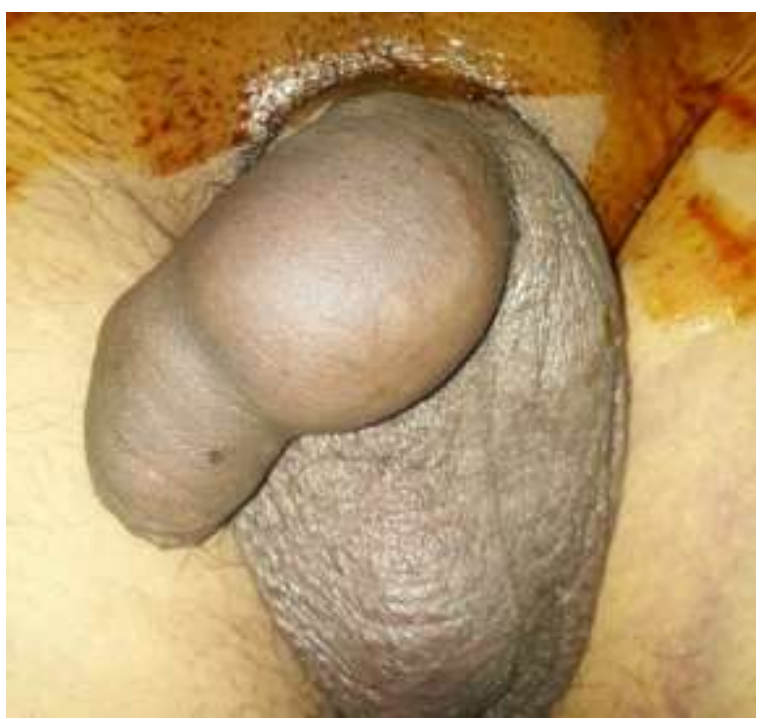

Fig-1: Dislocated testis in penile shaft with empty scrotum pouch on same side 


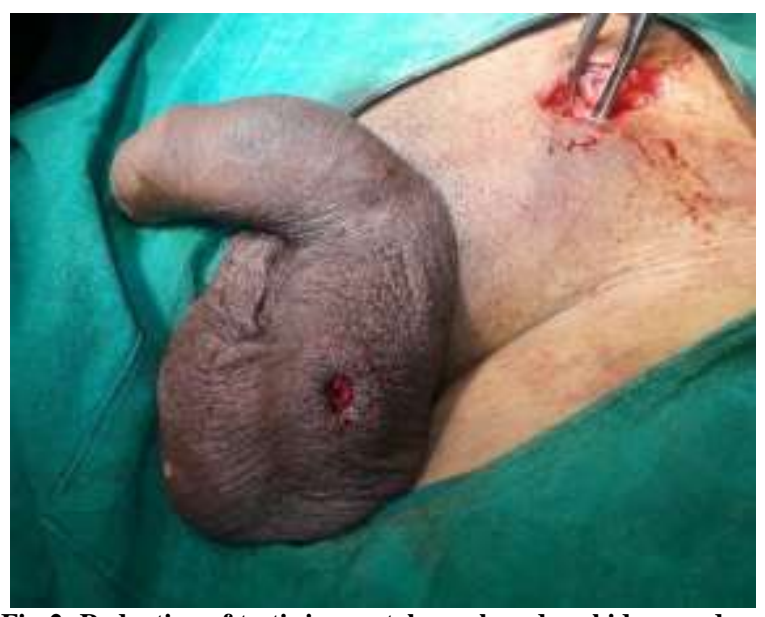

Fig-2: Reduction of testis in scrotal pouch and orchidopexy done

\section{DISCUSSION}

Delayed or missed diagnosis may be due to associated injuries or a lack of awareness of its possible occurrence. Delayed correction of traumatic testicular dislocation may result in infertility due to elevated temperature of testicles situated outside scrotal pouch [2].

Testicular injuries based on mechanism of injury can be divided into: (1) Blunt trauma, (2) Penetrating trauma, and (3) Degloving trauma. Such injuries are typically seen in male aged $15-40$ years [3].

The dislocation may be unilateral or bilateral. Possible sites and reported frequency of testicular dislocation [4]: Superficial Inguinal ring 50\%, pubic, penile, inguinal canal, intra-abdominal, perineal.

\section{CONCLUSION}

Risk of delayed reduction of testis is that torsion of the dislocated testis can be missed and an originally viable testis could become gangrenous. Surgical exploration and orchidopexy should be performed early to evacuate the hematoma, repair lacerated tissue, and fix the testicle after repositioning it.

In high speed two wheeler vehicle (generally Motorcycle) trauma always consider examining genital area of patient, which is possible cause of hidden injury in pelvic, perineal and perianal region, in which testicular trauma most common.

\section{REFERENCES}

1. Schwartz SL, Faerber GJ. Dislocation of the testis as a delayed presentation of scrotal trauma Urology, 1994; 43:743-745

2. Hayami S, Ishigooka M, Suzuki Y, Sasagawa I, Nakada T, Mitote K. Pathological changes of traumatic, dislocated testis. Urol Int. 1996; 56:129-32.

3. Ryan P, Terlecki MD. Is a member of the following medical societies: American Medical Association, American Urological Association, Phi Beta Kappa.

4. Schwartz SL, Faerber GJ. Dislocation of the testis as a delayed presentation of scrotal trauma. Urology 1994; 43:743. 